\title{
Environment and Bioeconomics: An Analysis of the Brazilian Ecosystem in Bioproducts Development
}

\author{
Tatiane Alves Baptista ${ }^{1}$, Rafaela Lora Grando ${ }^{2}$, Willy Jablonka ${ }^{3}$ and Renata Angeli ${ }^{4}$ \\ 1. Coordination of Strategic Studies and Development, Rio de Janeiro State University, Rio de Janeiro 20550900, Brazil \\ 2. Fiocruz, Rio de Janeiro, 21040900, Brazil \\ 3. Estácio de Sá University, Angra dos Reis 23914360, Brazil \\ 4. Technological Innovation Center-TTO, West Zone Statel University, Rio de Janeiro 23070200, Brazil
}

\begin{abstract}
This paper is part of an interdisciplinary and interinstitutional study ${ }^{1}$ involving biology, biotechnology and humanities researchers with the aim of examining the gaps as well as the opportunities that bioeconomics macrosegment offers to Brazil. For this, it adopted an action-research methodology based on interviews with stakeholders that work directly in the sector. Eighteen actors were contacted among researchers, experts and entrepreneurs, of which ten gave face-to-face interviews, with open questionnaires, semi-structured. From the analysis of these data, and from a vast theoretical framework, the article delimits biomass as a pillar of bioeconomics and points out the emerging trends of this science such as "green chemistry" and biotechnology. This is a field that condenses an important economic potential and a great capacity to develop mechanisms for the environment's preservation. By analyzing the production chain and its interfaces, the article reveals that Brazil, although it has an undeniable capacity to emerge as a world protagonist in sustainable production, still lacks well-defined public policies that invest in innovation, in addition to the consumer culture's transformation, production and economic development focused on non-renewable products.
\end{abstract}

Key words: Environment, bioeconomic, innovation, social development.

\section{Introduction ${ }^{1}$}

Bioeconomy may be considered as part of the solution to complex issues such as the scarcity of natural resources, aiming at a more balanced relationship between consumption and production of material goods [1]. This science refers to a time of transition where migration from a fossil-based economy to an economy based on renewable resources, especially biomass, is expected. Bioeconomics is not only a science, but it is also intended to be the integrating link between the society, the environment and the economy.

Briefly, bioeconomy is understood as the part of economy that uses biological resources (biomass), or

Corresponding author: Tatiane Alves Baptista, Ph.D., associate professor, researcher, research fields: management and governance of higher education for technology transfer, public policy and bioeconomy.

${ }^{1}$ Study conducted as part of PROINTER/SEBRAE-RJ (2018). bioprocesses, in order to produce value-added products such as food, materials, drugs, fuels, chemicals, etc. [2] or according to J. C. R. Lampkowski, and M. Lampkowski [3], the term bioeconomy is defined as the area that encompasses all sectors and their related services which produce, process or use any biological resources (biomass) regardless of their form [4].

From the perspective of the OECD (Organization for Economic Cooperation and Development), bioeconomics can be thought of as a segment in which biotechnology contributes to a significant portion of economic production. The emerging bioeconomy involves three essential elements: (i) use of knowledge in genetic engineering and cellular processes to develop new biological products; (ii) use of bioprocesses to support sustainable production and; (iii) cross-sectoral integration of knowledge and biotechnology [5]. 
Given the challenges surrounding the bioeconomy and the need to identify the gaps that prevent Brazil from converting all its theoretical sustainability capacity into opportunities, this article characterizes the current Brazilian scenario, pointing out its singularities according to the links of the biomass production chain. This chain embraces, from the raw material to the application of these residues in new bioproducts, observing its interface with the actors involved in the sector, stakeholders, the institutional environment, the investment scenario in the area and the industrial scale capacity.

\subsection{An overview of the Bioeconomy Strategies}

Globally, more than fifty countries have integrated the bioeconomy into their policy strategies, showing the strength and importance of this science. Notably, each nation's initiatives vary considerably. In the case of the United States, in its strategy known as Blue Print, the biomedicine, health and agriculture sectors are prioritized. Canada, on the other hand, prioritizes bioeconomic subsectors focused on research and development of new biomass and bioenergy based materials [6].

In the case of the European Union, the Europe's Bioeconomy Strategy program was launched in 2012 and addressed the production of renewable biological resources, their conversion into vital products and bioenergy [7]. It is interesting to note that the European program is structured around three pillars: investments in research, innovation and skills; enhanced policy interaction and interested parties' engagement; and markets improvement and competitiveness.

In this context, it is essential to point out that there is a wide variation in the policy objectives and strategic measures adopted by each country. These measures are characterized by the sector's industrial and economic prevalence, the profile and values adopted in each nation, and the available natural resources.
These strategies require measures that range from a political will to secure access until raw materials to a transformation of ecological awareness. Besides, the way nations engage their reference state bodies in bioeconomy also differs from nation to nation. Germany, Japan and the US have developed coordinated strategies involving various departments (Environment, Agriculture, Economics, Research, etc.) and have specific programs for bioeconomics. Other countries, such as Italy or Canada, support their initiatives in industry or in some regions of the country by limiting their strategy to the national level [6].

In Brazil's case, bioeconomics has become a strategic theme. In January 2017, the Ministry of Science, Technology, Innovations and Communications emphasized that actions focused on the theme are included in the National Science and Technology Strategy (Encti). Therefore, the shift from the energy matrix to renewable sources, as well as the supply of bioactive raw materials and molecules to the different branches of industry, promises to widen the range of opportunities for countries such as Brazil.

Finally, it is fundamental to understand the Brazilian market's dynamics. The National Confederation of Industry conducted a survey to map biotechnology in Brazil. In this study, it was found that $50 \%$ of the companies are located in the state of São Paulo, $11 \%$ in Minas Gerais and $10 \%$ in the state of Rio de Janeiro. In addition, $67 \%$ of them are national and $33 \%$ multinational. The size of these companies has been mapped and 63\% are large, $16 \%$ midsize and $21 \%$ small [8].

Brazil has considerable opportunity to participate in an even more meaningful way of bioeconomics through the production of high value-added products from the extensive biodiversity present here and from the large amount of biomass that can be an important source of essential bioproduct material. Strategies for the true meaning of a bioeconomy are associated with various environmental and socioeconomic objectives, 
such as climate protection, job creation, strengthening of economic innovation, as well as biodiversity and food security preservation [9], in addition to the supply of raw materials and bioactive molecules to the different branches of industry, they promise to broaden the range of opportunities for Brazil, reaffirming its strategic role regarding the environment.

The sources of biomass identified throughout this research as important inputs for creating opportunities were, as follows: woody vegetables (wood), non-woody (saccharides, cellulosic, starchy and aquatic), organic (agricultural, industrial, urban) and biofluid (vegetable oils). According to Laufenberg, et al. [10], such wastes may contain many high value-added substances and, by using effective technological strategies based on innovation and the future-bearing sciences, this biomass material with little or no utility can be converted into commercial products with high market value by activating the economy and generating sustainability.

\subsection{The Development of Green Chemistry: Bioproducts, Main Opportunity for Brazil}

One of the pillars of bioeconomy is the development of green chemistry for the generation of sustainable products. Its emergence dates from the early 1990s, mainly in the United States, England and Italy, with the introduction of new concepts and values for the various fundamental activities of chemistry, as well as for the various sectors of related industrial and economic activity [11].

However, in the early 1960s, Rachel Carson published the book Silent Spring, which describes the devastation of certain chemicals in local ecosystems. The book served as an alarm for both the public and the scientists, inspiring the modern environmental movement.

From this publication in 1969, the US Congress recognized the importance of the issue of sustainable development and passed a law aimed at "creating and maintaining conditions under which man and nature can exist in productive harmony". In subsequent years these issues were expanded and adopted by other nations. The OECD, an international body of over 30 industrialized countries, held meetings during the 1980s addressing environmental concerns, making a number of international recommendations that focused on cooperative change in existing chemical processes and in pollution prevention.

In the early 1990s, the European Community Chemistry Council published articles on the subject, including the work "Chemistry for a Clean World". Therefore, in this decade, the green chemistry has been consolidated around the world as an effective and transformative science, with the potential not only to reduce pollution but to minimize the effects of damages that had already been caused [12].

Considering the traditionally polluting products vis-à-vis green chemistry, with technological advancements and increasing global population, plastic materials have found wide applications in all aspects of life, generating new branches of the industrial sector. However, most conventional plastics, such as polyethylene, polypropylene, polystyrene, polyvinyl chloride and polyethylene terephthalate, are not biodegradable and their increasing accumulation in the environment has been a threat to the planet [13].

According to the European Bioplastics [14], bioplastics are boosting the evolution of plastics, having advantages over conventional plastic, since they save fossil resources through the use of regenerative biomass and have the potential of carbon neutrality.

In contrast, the biopolymers are polymers produced by living beings or obtained from raw materials from renewable sources, that can be found from the structure of DNA (Deoxyribonucleic Acid) to many products used for manufacturing plastic packaging. In the case of DNA - and other molecules, such as RNA (Ribonucleic Acid), proteins and enzymes, living organisms are responsible for their synthesis [15]. 
A major advantage of the biopolymers usage is their degradation in the environment, which results from the action of naturally occurring microorganisms such as bacteria, fungi and algae. In other words, biodegradation is the process of materials decomposition through biological activity, transforming the material into smaller molecules and causing a lower environmental impact. As a result, biopolymers are gaining more and more space due to properties that, at the same time, extend product life and make these materials' disposal easier [15].

In Rio de Janeiro, the law 8006 was passed in 2018, prohibiting the use of plastic straws. The law also demands the replacement of plastic by reusable or biodegradable bags, prohibiting the distribution or even sale of plastic bags in the state. This replacement must be made within 18 months for micro and small businesses, or 12 months for other establishments. In other states of Brazil, similar laws were created [16].

As it is known, biomaterials are devices consisting of artificial or natural compounds that are integrated into biological systems with the purpose of replacing, complementing or treating a particular organ or tissue whose function has been lost or damaged [17].

Compounds used for the production of biomaterials include natural or synthetic polymers (such as hydrogels), ceramics and metals (such as stainless steels and titanium or cobalt alloys). Examples of biomaterials include biomedical devices (such as biosensors, bloodstream tubes, hemodialysis systems), implantable materials (such as sutures, plaques, bone substitutes, tendons, meshes, heart valves, lenses, teeth), devices for the release of medicines (in the form of subdermal implants and particles), artificial organs (such as heart, kidney, liver, pancreas, lungs, skin) and bandages, among many others [17].

\subsection{Economic Potential and the Bioproducts Market}

The global market for bioproducts such as food, materials, drugs, fuels, chemicals etc., is expected to reach $\$ 714.6$ billion by 2021 [18]. This is due to the fact that basically all currently known chemicals can be replaced by bioproducts [19]. These are generally divided into groups: bioplastics, biopolymers, biochemicals, biomaterials, bioenergy/biofuels. Another rapidly developing market is the "composites", these are products structured from cellulosic fibers and their derivatives. These fibers may partially replace other materials such as plastic or cement.

Some of these products are often considered attractive because they could constitute new platforms, from which various end products would be derived, building an application tree for different end markets. These products have been called chemical platforms or platform-chemicals or platform molecules. For example, from a molecule such as succinic acid, an application platform can be produced, with advantages over the petrochemical route, performance and competitive cost. Established companies such as BASF, Purac, DSM and Roquette, and startups like Bioamber and Myriant, are currently moving to commercial-scale production of bioproducts [20].

\section{Methodology}

With the aim to characterize and delimitate the productive chain used for evaluating the interface links of all types of biomass, authors resorted to a combination of models proposed in the literature as: Refs. [21-24]. In this methodology, the design of the production chain consists of the chain's delimitation, identifying the segments that compose it, as well as the physical flow of materials from the origin (segment inputs) to their final application.

In order to have a close approximation and so that the results could be validated, authors adopted the action-research methodology through the interview with actors who work directly in the sector, according to Fig. 1. In this sense, it was important to hear especially from academics and business people. Although contacts were made by invitation letter to 18 informants, only 10 were willing to attend. 


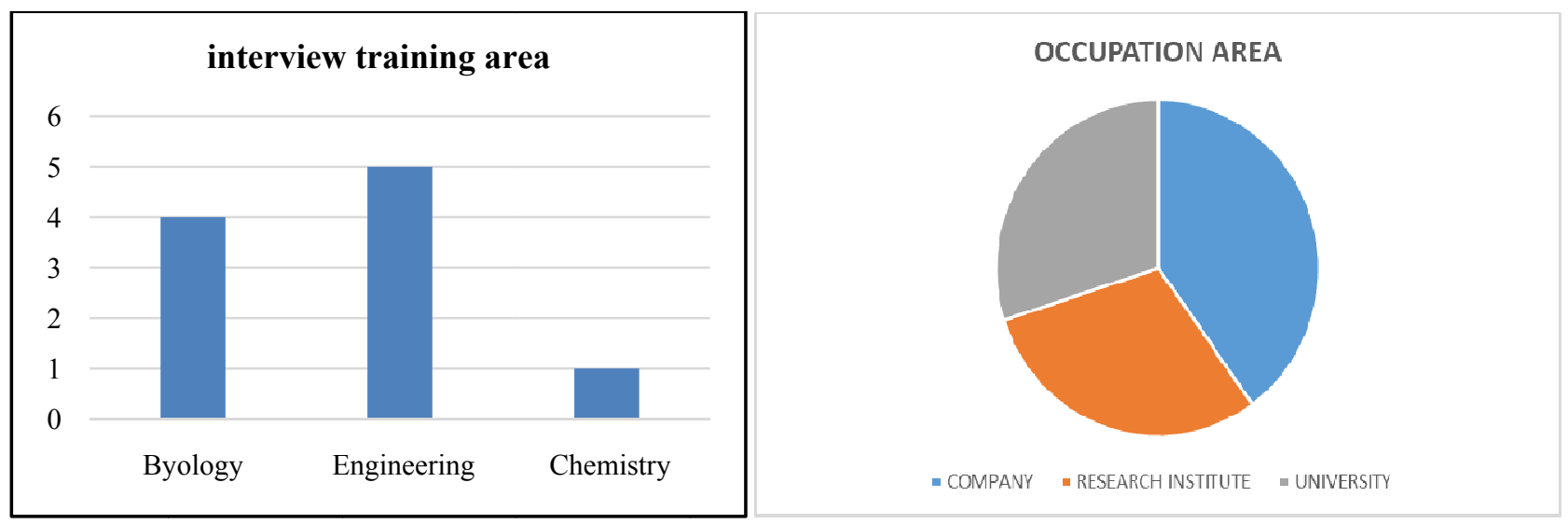

Fig. 1 The profile of the interviewed actors, considering the area of training and market insertion.

\section{Results and Discussion}

\subsection{Biomass Production Chain and Its Interfaces: The} Brazilian Case

The AFNOR (Association Française de Normalisation) has adopted a broader concept, considering the production chain as a set of changes of the raw material, with economic purpose, which includes since the exploitation of this raw material in its natural environment, until its return to nature, through the production, consumption, recovery, treatment and disposal circuits of effluents and solid wastes.

Moreover, it can be said that sustainable supply chain is responsible for all this, always concerned about the environment by trying to reduce the impact of each action.

According to the study, the Fig. 2 consist of the links and interfaces of the biomass productive chain.

It is important to mention that there is not yet in Brazil an industrial park for the generation of biomass products. Thus, most of what has currently been done, in terms of technology, is found in universities and research centers. These data point to the strategic role that these institutions play in terms of the sector's development.

Indeed, Brazil has some companies that are starting to develop some of the chain's stages. Also, there are countless emerging technology-based companies, supported by public funding (grants) and by significant venture capital investments, in addition to the participation of established companies from various industrial sectors, usually technology-based and university startups.

It is considered as institutional environment, from public policies to the culture that exists in the population still strongly based on fossil products, the movement of the sector by debates and specific events bringing together actors from the area, besides the actors involved with the legal field: legislation and legislation aimed at the protection of intellectual property.

The INPI (National Institute of Brazilian Industrial Property) has a program called "Green Patents", aimed at accelerating the analysis of patent requirements for technologies that deal with sustainable matters, and has been active since 2013 . The program's goal is to accelerate the entrance of innovations related to the theme in the market. Universities already have specific Masters and Doctorate courses in green chemistry and biomass use, which positively points to overcoming a historical bottleneck in the country, the issue of skilled human resources [25].

According to the study, in Brazil's case, there are issues in the instructional scope, also related to misinformation and, therefore, there are difficulties of interaction among the actors of the various spheres of the institutional environment. 
GENERIC PRODUCTION CHAIN: Biomass/Waste

\begin{tabular}{|c|c|c|c|c|c|c|}
\hline $\begin{array}{c}\text { LINK } \\
\text { INTERFACES }\end{array}$ & BIOMASS & LOGISTICS & $\begin{array}{c}\text { PRE } \\
\text { TREATMENT }\end{array}$ & CONVERSION & PRODUCTS & APLICATION \\
\hline STAKEHOLDERS & $\begin{array}{l}\text { Biomass production } \\
\text { companies } \\
\text { Waste generation } \\
\text { companies/industries }\end{array}$ & $\begin{array}{l}\text { Biomass transportation } \\
\text { companies }\end{array}$ & $\begin{array}{c}\text { Universities } \\
\text { Research institutions }\end{array}$ & $\begin{array}{c}\text { Universities } \\
\text { Research institutions }\end{array}$ & $\begin{array}{l}\text { Biofuels } \\
\text { Biopolimers } \\
\text { Biomaterials } \\
\text { Green industries }\end{array}$ & $\begin{array}{l}\text { Sustainable Product } \\
\text { Industries Replacing Fossil } \\
\text { Resources } \\
\text { Green chemistry } \\
\text { Biorrefinary }\end{array}$ \\
\hline $\begin{array}{l}\text { INSTITUTION } \\
\text { ENVIRONMENT }\end{array}$ & $\begin{array}{c}\text { Meetings } \\
\text { Legislation } \\
\text { Public policy }\end{array}$ & $\begin{array}{l}\text { Meetings } \\
\text { Legislation } \\
\text { Public policy }\end{array}$ & $\begin{array}{l}\text { Meetings } \\
\text { Legislation } \\
\text { Public policy } \\
\text { Patents, copyrights }\end{array}$ & $\begin{array}{l}\text { Meetings } \\
\text { Legislation } \\
\text { Public policy } \\
\text { Patents, copyrights }\end{array}$ & $\begin{array}{l}\text { Meetings } \\
\text { Legislation } \\
\text { Public policy } \\
\text { Patents, copyrights }\end{array}$ & $\begin{array}{c}\text { Meetings } \\
\text { Legislation } \\
\text { Public policy } \\
\text { Patents, copyrights } \\
\text { Import/export }\end{array}$ \\
\hline $\begin{array}{c}\text { FUNDING/ } \\
\text { INVESTMENTS }\end{array}$ & Not applied & Not applied & $\begin{array}{c}\text { Public } \\
\text { Private sector }\end{array}$ & $\begin{array}{c}\text { Public } \\
\text { Private sector }\end{array}$ & $\begin{array}{c}\text { Public } \\
\text { Private sector }\end{array}$ & Not applied \\
\hline SCALE & Not applied & Not applied & $\begin{array}{c}\text { Laboratory } \\
\text { (P\&D) } \\
\text { Pilot/Prototyping }\end{array}$ & $\begin{array}{c}\text { Laboratory } \\
\text { (P\&D) } \\
\text { Pilot/Prototyping }\end{array}$ & Industrial & Not applied \\
\hline
\end{tabular}

Fig. 2 Generic biomass production chain.

Interfaces: they are the agents that interrelate with the chain links.

Stakeholders (directly or indirectly interested in each phase of the chain): (1) biomass producing companies; (2) waste producing companies; (3) biomass carriers; (4) public and private universities, research centers and research institutions.

Source: the authors, 2018.

Investment programs, interested in investing in the chain stages, aim to maximize results or seek system improvement in an institutional manner. Grants, loans, funding and other models can be placed under individuals or companies. There are already investments focused on sustainability, known as green investment funds, which are funds willing to invest in sustainable businesses, with different prices.

In the United Kingdom, there are at least 80 funds of this type, reaching some $\$ 44$ billion (in Brazil about $\$ 315$ million). In the US, there are at least 180 funds, totaling $\$ 9.3$ trillion. In Brazil, we can exemplify the sustainable funds of banks: Safra, Banco do Brasil, Bradesco, Santander, Unibanco, Caixa and the Votorantim Group.

Still with regard to investments, it should be noted that in this sector there are a large number of innovative projects in competition, proposing different solutions to the same problem: the rational use of natural resources.

We cannot affirm, for instance, that the biochemical route is better than any of the thermochemical ones. However, such projects have great dynamism related with both new creative proposals and their continuity in the market, since these new projects are in the trial phase. Therefore, investments and financial support at this stage, especially grants or economic subsidy with lost funds are extremely important [26].

In the European Union, there is a partnership-Bio-based Industries Consortium, public-private, that leverages investments and reduces the investment risk for the sector. Of the total project budget of $€ 3.7$ billion, almost $75 \%$ will be invested by biomass and based industries, totaling $€ 2.7$ billion from 2014-2020.

Studies show that across Europe, in 2016, industries of this nature have already invested more than 4 
billion euros in infrastructure. Most of short-term investments occur in the lignocellulosic and forest biomass value chains. Projects include the transition from first-generation to second-generation of ethanol production, as well as the expansion of chemical building production in blocks, the production of food grade MFC (Microfibrillary Cellulose) and the creation of a new production plant, materials and chemical building blocks of lignin and cellulose streams to the pulp and paper industry (Bio Based Industries Consortium, 2018).

The volume (quantity/size) of the operation performed at that process stage refers to the scale. Such scales may be described as laboratory level, basic R\&D (Research and Development), pilot and prototype, and industrial level for each phase. During this study's elaboration, a great concern was noticed, especially of the interviewees regarding the scale, that is, there is a feeling of care regarding the choice of the raw material since it necessarily has to be constant and continues to become scalable. For example, inputs with seasonality can cause problems in the industrial phase, and the cost of transporting this raw material has to be as low as possible given the large volume of resources needed to develop technological solutions.

For one of the respondents, there are opportunities in this aspect of scale. This is because the combination of new product development is a source of raw material, allows scale and reduces logistics costs.

The full and rational use of lignocellulosic raw materials could revolutionize a number of industrial segments, such as liquid fuels, food and chemical inputs, bringing immeasurable benefits to countries with large territorial extensions and high biomass productivity, among which Brazil occupies a prominent position. Despite the great potential of this raw material, much of this agro-industrial waste is burned in power plants and a smaller fraction is used in the composition of animal feed, with surpluses still remaining.

\section{Conclusion}

The sustainability of (bio) product value chains within the use of different types of plant biomass (starchy, lignocellulosic, oleaginous and saccharide) will be consolidated as an alternative to the use of cheaper and less polluting raw materials within a model of adding economic value to agro-industrial chains, such as soybean, sugar cane, corn and forest residues, among others. This use of plant biomass will replace that of petroleum-derived fossil resources in the production of a wide range of products of mainly organic origin such as plastics which is, for example, widely used in today's society.

Thus, it is observed that the use of plant biomass by the chemical industry is perceived as a new possibility for business and the generation of economic income for the country, in addition to promoting a worldwide trend towards improving environmental impacts.

On the other hand, the need to develop technologies in order to obtain these (bio) products presents considerable technical and scientific bottlenecks and economic viability in the current market.

In this context, although Brazil is rich in terms of solar energy with biomass generation, and, therefore, in residues produced by agribusiness biomass, it does not yet have the concept of integrated refinery to what is currently produced through use of petroleum in fuels and their derivatives.

It is in this field of integration between the petrochemical platform and the valorization of biorefineries that we must, therefore, advance in the coming years if Brazil intends to build a rich economy based on the use of vegetal biomass for the making of products used by the whole society nationally and internationally. This, of course, will depend on the paths estimated by public policies for the sector in the country.

The article concludes, by analyzing this picture, that Brazil has great relevance in the world scenario, due to its prominent position in knowledge, vis-à-vis its 
installed capacity in research and innovation, universities and research centers, and, above all, its great biodiversity. However, we still face the need to develop technologies in order to obtain these (bio) products, since the country has considerable bottlenecks, especially related to an economic development model focused on oil and its derivatives.

The study made it clear that while there is a huge potential for new bioproducts originated from biomass, not all processes are consolidated or on a commercial scale. There are still several challenges that require research, development and especially investment and incentive policies to become a competitive option for traditional non-renewable products. In Brazil, the sectors of the biomass-based economy are still emerging and do not yet have a defined industrial structure, so they are dynamic, active and based on innovation [20].

\section{References}

[1] Bugge, M., Hansen, T., and Klitkou, A. 2016. "What Is the Bioeconomy? A Review of the Literature." Sustainability $\quad$ 8: 691-702. http://dx.doi.org/10.3390/su8070691.

[2] Patermann, C., and Aguilar. 2018. "The Origins of the Bioeconomy in the European Union." New Biotechnology.https://www.researchgate.net/publication/ 316041150_The_origins_of_the_Bioeconomy_in_the_Eu ropean_Union.

[3] Lampkowski, J. C. R., and Lampkowski, M. 2019. "Considerações sobre a bioeconomia e sua relação com os produtos bio-based." Caderno Meio Ambiente $e$ Sustentabilidade 9: 54-62. (in Portuguese)

[4] Bioökonomierat. 2010. Bio-Economy Council Report: Bioeconomy Innovation. German Bioeconomy Council.

[5] OECD. 2013. "Policies for Bioplastics in the Context of a Bioeconomy." OECD Science, Technology and Industry Policy Papers, No. 10, OECD Publishing. http://dx.doi.org/10.1787/5k3xpf9rrw6d-en.

[6] Bioeconomy Council. 2015. "Bioeconomy Policy Synopsis and Analysis of Strategies in the G7." German Bioeconomy Council. Accessed September 29, 2019. https://biooekonomierat.de/fileadmin/Publikationen/beric hte/BOER_Laenderstudie_1_.pdf.

[7] European Commission. Accessed September 29, 2019. https://ec.europa.eu/research/bioeconomy/index.cfm?pg= policy\&lib=strategy.
[8] Confederação Nacional da Indústria. 2014. "Bioeconomia: oportunidades, obstáculos e agenda.” CNI. (in Galician)

[9] Budzianowski, W. M. 2016. "High-Value Low-Volume Bioproducts Coupled to Bioenergies with Potential to Enhance Business Development of Sustainable." Biore Fi Neries. 70: 793-804.

[10] Laufenberg, G., Kunz, B., and Nystroem, M. 2003. "Transformation of Vegetable Waste into Value Added Products: (A) The Upgrading Concept; (B) Practical Implementations." Bioresource Technology 87: 167-98.

[11] Silva, A. J. G. 2010. "Biorrefinarias-Rota bioquímica." In Química verde no Brasil: 2010-2030. Brasília: CGEE. (in Portuguese)

[12] American Chemical Society. Accessed September 29, 2019. https://pubs.acs.org/journal/jacsat.

[13] Yutaka, T., Calabia, B. P., Ugwu, C. U., and Seiichi, A. 2009. "Biodegradability of Plastics." International Journal of Molecular Sciences 10 (12): 3722-42. http://dx.doi.org/10.3390/ijms10093722.

[14] OECD. 2014. "Biobased Chemicals and Bioplastics: Finding the Right Policy Balance." OECD Science, Technology and Industry Policy Papers, No. 17, OECD Publishing. http://dx.doi.org/10.1787/5jxwwfjx0djf-en.

[15] Pradella, J. G. 2006. Biopolímeros e Intermediários Químicos. Centro de Gestão e Estudos Estratégicos (CGEE). (in Galician)

[16] ALERJ. 2019. Accessed September 29, 2019. http://www3.alerj.rj.gov.br/lotus_notes/default.asp?id=7 \&url=L3NjcHJvMTUxOS5uc2YvMTA2MWY3NTlkOT dhNmIyNDgzMjU2NmVjMDAxOGQ4MzIvZjk5Mjc2N 2ZlZTRjZjdhNjgzMjU4MjJkMDA2MTU4ZTY/T3Blbk RvY3VtZW50.

[17] Winstel, L. 2017. "Top Value Added Chemicals: The Biobased Economy 12 Years Later, 2017." Accessed September 29, 2019. https://communities.acs.org/ community/science/sustainability/green-chemistry-nexusblog/blog/2017/03/16/top-value-added-chemicals-the-bio based-economy-12-years-later.

[18] Research and Markets. 2017. Global Biorefinery Products Market Report 2017: Market to Reach \$714.6 Billion by 2021 from \$466.6 Billion in 2016-Research and Markets.

[19] Junio, C., Joachim, V., Hoffmam, Z. B., and Ribeiro, L. F. 2016. "Frontiers in the Expansion of Bioproducts." Biomed Research International, Article ID 3809386. doi: 10.1155/2016/3809386.

[20] Bomtempo, J. V., Alves, F., and Oroski, F. 2017. "Bioeconomia em construção XII-Bioeconomia no Brasil: explorando questões-chave para uma estratégia nacional." (in Portuguese)

[21] Castro, A. M. G. de, Lima, S. M. V., Goedert, W. J., Freitas, F. A., and Vasconcelos, J. R. P. 1998. 
"Prospecção tecnológica de cadeias produtivas e sistemas naturais." Empresa Brasileira de Pesquisa Agropecuária. Departamento de Pesquisa e Desenvolvimento. Embrapa-DPD 568. (in Portuguese)

[22] Castro, A. M. G. 2002. "Cadeia produtiva e prospecção tecnológica como ferramenta para a gestão da competitividade.” In Simpósio de Gestão de Tecnologia. Salvador: Anais, 22. (in Portuguese)

[23] Lamprinopoulou, C., Renwick, A., Klerkx, L., Hermans, F., and Roep, D. 2014. "Application of an Integrated Systemic Framework for Analysing Agricultural Innovation Systems and Informing Innovation Policies." Agricultural Systems 129: 40-54.

[24] Correll, D., Suzuki, Y., and Martens, B. J. 2014.
"Logistical Supply Chain Design for Bioeconomy Applications." Biomass And BioenergY 66: 60-9. https:/www.springerprofessional.de/en/an-overview-of-c urrent-models-and-approaches-to-biomass-supply-c/1581 8594.

[25] Padua, V. L. M., Chagas, E. F., Baptista, T. A., Macrae, F. R. T., Stephens, P. R. S., Paes, M. C., Salerno, A. P., Oliveira, A. M. C., Queiroz, R., and Rozental, D. U. 2018. "Recursos Humanos em Biotecnologia: instituições, formação e mercado de trabalho no Estado do Rio de Janeiro.” Sinergia 19: 126-32. (in Portuguese)

[26] Cruz, A. C., Pereira, F. S., Costa, L. M., and Oliveira e Silva, M. F. 2014. "Química verde na ótica dos agentes de mercado.” BNDES Setorial 39: 5-54. (in Portuguese) 